\title{
Target Group Behavior for Policy Performance Impact: Study on Poverty Reduction Implementation in Makassar, Indonesia
}

\author{
Anirwan ${ }^{1}$, Muhammad Akmal Ibrahim ${ }^{2}$, Hasniati $^{2}$, Suryadi Lambali ${ }^{2}$ \\ ${ }^{1}$ Doctoral Program in Public Administration, Faculty of Social and Political Sciences, \\ Hasanuddin University, Indonesia \\ ${ }^{2}$ Faculty of Social and Political Sciences, Hasanuddin University, Indonesia \\ Received: August 1, 2021 \\ Received in Revised: August 25, 2021 \\ Accepted: September 2, 2021
}

\begin{abstract}
The implementation of poverty reduction policies in Makassar City is still reaping many problems. Various poverty reduction programs launched by the government have not been able to eradicate poverty effectively. In the implementation of these various poverty reduction programs, the response of the target group tends to be negative, causing fragmentation at the level of implementation. Therefore, this study aims to identify and analyze the process of implementing poverty reduction policies in Makassar City from the perspective of group behavior. The research method used is a qualitative method with data collection techniques through in-depth interviews, field observations, and review of poverty documents. The research data were analyzed by qualitative analysis. The results show that the community is basically very responsive to the existence of poverty reduction policies in the form of multi-purpose social security assistance distributed by the Makassar City Social Service because some of them feel helped by the assistance, but some also feel that the policies are not well targeted due to incomplete data collection. equitable and fair. The inaccuracy of policy targets (assistance for beneficiaries) for the poor causes social jealousy in the community which has an impact on street level publicity and policy performance so that it does not significantly reduce poverty in Makassar City.
\end{abstract}

Keywords: Behavior, Responsiveness, Poor Community, Policy Implementation Introduction

Presidential Regulation of the Republic of Indonesia Number 15 concerning the Acceleration of Poverty Reduction states that poverty reduction is a policy and program of the central government and/or regional government which is carried out in a systematic and planned manner, and synergizes with the business world and the community to manage the number of poor people in order to improve the degree of community welfare. One of the main indicators of the success of a country's economic growth can be seen from its poverty rate (Laoh, et al, 2016 Jaka Sriyana, 2021). Thus, poverty is one of the main themes in development. Development success and failure are often measured by changes in poverty levels (Sulistyaningrum, 2013; Murdiansyah, 2014; Laoh, et al, 2016). Therefore, poverty is a development problem which is characterized by unemployment, underdevelopment, and adversity (Abu-Ras \& Mohamed, 2018).

Poverty is not only a problem in Indonesia, but also a problem that is being faced by various countries internationally. In an effort to overcome the problem of poverty, the United Nations (UN) has set the Millennium Development Goals (MDGs). One of the main goals of the MDGs is to eradicate poverty and hunger which need serious attention from the Government. In 2012 the United Nations carried out the SDGs agenda as a continuation and expansion of the 
Millennium Development Goals (MDGs) that had been carried out by countries from 2001 to the end of 2015. The Sustainable Development Goals explicitly aim to eradicate poverty and hunger, reduce inequality within and between countries, improve water and energy management, and take urgent steps to address climate change (De Muro, 2011; Langford, 2012; International Conference on Public Health, 2012).

Based on data from the Central Statistics Agency (BPS), in March 2012 the number of poor people in Indonesia was recorded at 29.25 million or $11.96 \%$. Then in the period of March 2013 the number of poor people in Indonesia was 28.17 million or 11.36\%. Furthermore, in March 2014 the number of poor people was recorded at 28.28 million or 11.25\%. Then in March 2015 the number of poor people was 28.59 million or 11.22\%. Entering March 2016, the poor population was 28.01 million or $10.86 \%$. Then in March 2017 the poor were recorded at 27.77 million or $10.64 \%$. Finally, in March 2018 the number of poor people was recorded at 25.95 million people or 9.82 percent. The data also states that the number of poor people in urban areas for the 2018 period was recorded at 10.14 million, down 12.82 thousand people compared to the September 2017 period of 10.27 million. Meanwhile, in terms of the percentage of poor people in urban areas, it was $7.02 \%$ lower than the September 2017 period of $7.26 \%$.

The Central Government in tackling poverty in Indonesia is guided by Law Number 13 of 2011 concerning Handling the Poor. Subsequently, Presidential Regulation Number 96 of 2015 concerning Amendments to Presidential Regulation Number 15 of 2010 concerning the Acceleration of Poverty Reduction was issued (Prawoto, 2008; Soleh, 2014; Pratama, 2014).

To measure poverty, BPS Makassar City uses the concept of ability to meet basic needs. With this approach, poverty is seen as an economic inability to meet basic food and non-food needs as measured from the expenditure side. The method used is to calculate the Poverty Line (GK), which consists of two components, namely the Food Poverty Line (GKM) and the Non-Food Poverty Line (GKNM). The Food Poverty Line (GKM) is the value of spending on minimum food needs which is equivalent to 2,100 calories per capita per day. The Non-Food Poverty Line (GKNM) is the minimum need for housing, clothing, education, health and other basic needs (BPS, Makassar in Figures 2021).

Based on data from the Makassar City Central Statistics Agency, the data on the poor population of Makassar City from 2013-2020 can be seen in the following table:

Table 1. Poverty Line, Number, and Percentage Makassar City's Poor in 2013 - 2020

\begin{tabular}{|c|c|c|c|}
\hline Year & $\begin{array}{c}\text { Mymicsinan Line } \\
\text { (Rupiah / capita / } \\
\text { month }\end{array}$ & $\begin{array}{c}\text { Number of Poor } \\
\text { People (Thousand) }\end{array}$ & $\begin{array}{c}\text { Percentage of } \\
\text { poor people }\end{array}$ \\
\hline 2013 & 273231 & 66,4 & 4,70 \\
\hline 2014 & 281917 & 64,23 & 4,48 \\
\hline 2015 & 2194 & 63,24 & 4,38 \\
\hline 2016 & 347723 & 66,78 & 4,56 \\
\hline 2017 & 366430 & 68,187 & 4,59 \\
\hline 2018 & 386545 & 66,22 & 4,41 \\
\hline 2019 & 418831 & 65,12 & 4,28 \\
\hline 2020 & 442513 & 69,98 & 4,54 \\
\hline
\end{tabular}

Source: BPS Data, Makassar in Numbers 2021

The table above shows that the percentage of poverty in Makassar City in the last 8 (eight) years, namely from 2013 to 2020 is around 4 percent more per year. The trend of decreasing poverty rates in Makassar City is 0.16 percent for the last 8 (eight years, namely from 2013-

Copyright $($ C 2021, Journal of Asian Multicultural Research for Social Sciences Study, Under the license CC BY-SA 4.0 
2020. This illustrates that the implementation of poverty reduction policies does not significantly reduce the poverty rate every year. While the Index of Depth and Severity of Poverty in Makassar City can be seen in the table below:

Table 2. Poverty Depth Index and Poverty Severity in Makassar City 2013-2020

\begin{tabular}{|c|c|c|}
\hline Year & Poverty Depth Index & Poverty Severity Index \\
\hline 2013 & 0,84 & 0,24 \\
\hline 2014 & 0,72 & 0,19 \\
\hline 2015 & 0,60 & 0,12 \\
\hline 2016 & 0,67 & 0,16 \\
\hline 2017 & 0,64 & 0,13 \\
\hline 2018 & 1,11 & 0,38 \\
\hline 2019 & 0,60 & 0,15 \\
\hline 2020 & 0,58 & 0,12 \\
\hline
\end{tabular}

Source: BPS Data, Makassar in Numbers 2021

The table above shows that the Poverty Gap Index (Poverty Gap Index-P1) from 2013 to 2020 is still relatively low and declining, which means that the level of expenditure gap for the poor is still relatively high. While the Poverty Severity Index (Poverty Severity Index-P2) shows that from 2013 to 2020 it is still relatively low, meaning that the disparity in spending among the poor is still relatively high. This shows that the poverty reduction policy in Makassar City does not significantly reduce the poverty rate.

In order to accelerate poverty reduction in Makassar City, Makassar City Government refers to Makassar City Regional Regulation Number 11 of 2002 concerning the Establishment of Makassar City Poverty Reduction Coordination Team. In order for the Regional Regulation to be implemented, the Makassar City Government then issued Makassar Mayor Regulation Number 70 of 2015 concerning the Strategy for the Acceleration of Poverty Reduction in Makassar City for 2015-2019. One of the targets of the vision and mission of the City of Makassar is the realization of social security for poor families as a whole. To achieve this target, the Makassar City Government has set a strategy for coordinating the implementation and sharpening of target beneficiaries in the poverty reduction movement with regional development programs, namely 1) a poverty reduction coordination program, 2) a multipurpose social security program for poor families, (RPJMD Makassar City, 2014-2019).

The problem of poverty raises various problems making poverty a priority that must be addressed immediately, in this case is the problem of poverty faced by the Makassar City Government. Therefore, the handling of poverty must receive special attention by the Makassar City government so as not to cause problems that can hinder the development process. One of the strategic issues in the social sector in Makassar City is poverty. The poverty rate is still quite high, and data collection is still not uniform to be one of the obstacles in alleviating poverty, especially in health services for poor families (Jaha \& Sika-Bright, 2015). Referring to this issue, the problem of poverty in Makassar City is still a crucial issue. This is of course closely related to the issue of poverty policy and its implementation. One of the variables that influence the success of policy implementation according to Winter (2003) is the behavior of the target group (target group behavior). Organizational behavior is a study of human behavior, attitudes, and the results of their work within the scope of the organization (Kehoe \& Wright, 2013; Ibrahim $\&$ Aslinda, 2017). This is in line with the behavior of the target group (target group behavior) in the implementation of poverty reduction policies, which is an organization that carries out policies in which there are policy implementers and policy targets. 
Poverty reduction policies are central government programs that are implemented by the regions so that they tend to ignore the facts of poverty in the regions causing a lack of innovation in tackling poverty which has implications for weak poverty reduction policies (Ortiz, 2002). In addition, poverty reduction policies prioritize aspects of economic growth. This is emphasized in the Makassar Mayor Regulation Number 70 of 2015 article 1 paragraph (8) that poverty reduction is a policy and program of the central and or regional governments that is carried out systematically, planned and in synergy with the business world to reduce the number of poor people in order to improve the degree of welfare. people. Furthermore, paragraph (9) emphasizes that poverty reduction programs are activities carried out by the government, provincial, district/city governments, the business world, and the community to improve the welfare of the poor through multi-purpose social security assistance, community empowerment, empowerment of micro-enterprises., small and medium enterprises as well as other programs in order to increase economic activity. This illustrates that poverty reduction policies are central government programs implemented by regions that are more oriented towards improving the economy of the poor so that they pay less attention to the aspects of equity, justice, and welfare for the poor. The results of the study by Suratman et al., 2017) found that the importance of using transformed cultural and religious values in the concept of empowering the poor.

From the description above, it shows that the phenomenon of poverty in Makassar City is still quite severe. On the one hand, various poverty reduction programs launched by the government have not been able to effectively eradicate poverty. In the implementation of these various poverty reduction programs, the response of the target group tends to be negative, causing pragmentation at the level of implementation. Conceptually and phenomenally, poverty alleviation involves various stakeholders, so it requires stakeholder integration that aims to achieve success in policy implementation.

\section{Methods}

This research is the result of a qualitative research that aims to analyze poverty alleviation from the behavioral aspect of the target group (target group). The research location is in Makassar City. Data was collected through interviews, observation, and documentation. Interviews were conducted with informants, in this case the Office of Social Affairs, District, Kelurahan, and Rukun Neighbors throughout Makassar City, the poor, and poverty observer institutions. Observations were made through direct object observations and existing documentation related to poverty alleviation policies. The data analysis used is descriptive qualitative, namely describing and analyzing the data obtained to get a conclusion.

\section{Results and Discussion}

Winter (2003) emphasized that the success of policy implementation is also influenced by variables in the implementation process, namely: (1) organizational and inter-organizational behavior; (2) lower-level bureaucratic behavior (street level bureaucratic behavior); (3) the behavior of the target group (target group behavior) which not only influences the effect/impact of policies, but also affects the performance of lower-level bureaucrats/apparatus. One of the variables that influence the success of policy implementation according to Soren C. Winter is the behavior of the target group which is the focus of the study in this study. The behavioral variables of the target group not only have an effect on the effect/impact of the policy, but also affect the performance of lower-level bureaucrats/apparatus. This variable looks at the extent to which the positive and negative responses of the poor have an impact on the policies and performance of lower-level implementers (street level hearings). 
Based on interviews from several informants, they illustrate that some of the poor feel helped by the poverty reduction assistance distributed by the Makassar City Social Service, but some poor people also feel that a lot of multi-purpose social security assistance is not right on target, namely people who should be entitled to receive social security assistance. assistance, but cannot receive assistance because it is not recorded in the Social Welfare Integrated Data (DTKS). On the one hand, the community should not be entitled to receive assistance, but it is recorded in the Integrated Social Welfare Data (DTKS) so that they are entitled to receive assistance.

The poor as the target of the program (beneficiaries) really hope for assistance that can help their daily needs (Banerjee et al., 2015). However, the data collection that is not valid and accurate causes many people who have not received assistance. The success of a policy implemented in this case poverty reduction is largely determined by valid and accurate data collection as the basis for the poor (beneficiaries) to receive targeted assistance. The poor (beneficiaries) are the main target of various poverty reduction programs. The successful implementation of poverty reduction policies begins with collecting data on people who meet the poor category that has been determined by the government as the basis for distributing aid.

The results of research in the field related to the behavior of the target group can be described: 1) The behavior of a number of individuals who use social assistance to reduce poverty in the election of regional heads, thus influencing the behavior of the target group to determine their political choices; 2) Based on the results of the interview, it shows that there is an indifferent attitude from the community towards the administrative completeness process such as managing Family Cards and other administration so that it is difficult to detect by the system as the target beneficiary; and 3) The indifferent behavior of the beneficiary groups has an influence on data problems, so that there are some people who actually deserve assistance but have not yet accessed the assistance. This is because the data used in the process of updating beneficiaries still refers to data that has not been updated.

The negative response related to the program is considered not yet right on target for the people who deserve it, where it is suspected that there are beneficiaries who are prioritized because of their proximity to the local government, even though there are still families who are more worthy to receive assistance. There are also certain individuals who take advantage of the poverty alleviation assistance program to gain electoral advantage in order to be elected in political elections. This condition reflects the vulnerability of the poverty reduction assistance program to be politicized, so it requires supervision from the relevant agencies and direct reports from the community will be followed up to the authorities.

But overall, the existence of a social assistance program under the scope of work of the Makassar City Social Service is very beneficial for the community. Right on target, the aid program from the government begins with the good data collection contained in the Integrated Social Welfare Data (DTKS). Therefore, the role of lower-level implementers to validate data and active community participation is needed so that the poverty rate in Makassar City can be suppressed.

\section{Conclusion}

The results show that there are still many people who have not been registered as poor in the Makassar City Social Service through the Social Welfare Integrated Data (DTKS) so that these people should receive multi-purpose social security assistance, but in reality on the ground they do not receive multi-purpose social security assistance from government. On the one hand, some people should not be entitled to receive multi-purpose social security assistance, but in reality they receive multi-purpose social security assistance from the government because it is 
recorded in the Integrated Social Welfare Data (DTKS). The community is basically very responsive to the existence of poverty reduction policies in the form of multi-purpose social security assistance distributed by the Makassar City Social Service because some of them feel helped by the assistance, but some also feel that the policies are not well targeted due to uneven and fair data collection. . The inaccuracy of policy targets (assistance for beneficiaries) for the poor causes social jealousy in the community which has an impact on the performance of lower-level implementers (street level publicity) and policies so that it does not significantly reduce the poverty rate in Makassar City

\section{References}

Abu-Ras, W., \& Mohamed, R. A. (2018). Child poverty and youth unemployment in Palestine. Poverty \& Public Policy, 10(3), 354-370.

Banerjee, A., Duflo, E., Goldberg, N., Karlan, D., Osei, R., Parienté, W., ... \& Udry, C. (2015). A multifaceted program causes lasting progress for the very poor: Evidence from six countries. Science, 348(6236).

De Muro, P., Mazziotta, M., \& Pareto, A. (2011). Composite indices of development and poverty: An application to MDGs. Social indicators research, 104(1), 1-18.

Ibrahim, M.A \& Aslinda. (2017). Organizational Citizenship Behavior dan Kinerja Organisasi. Yogyakarta, Capiya Publishing.

Jaha, I. R., \& Sika-Bright, S. (2015). Challenges of the Livelihood Empowerment Against Poverty programme in the Upper West region of Ghana: the institutional perspective. UDS International Journal of Development, 2(1), 188-205.

Jaka Sriyana, S. E., Abdul Hakim, S. E., \& Afandi, A. (2021). Analisis Kebijakan Penanggulangan Kemiskinan Di Indonesia.

Kehoe, R. R., \& Wright, P. M. (2013). The impact of high-performance human resource practices on employees' attitudes and behaviors. Journal of management, 39(2), 366391.

Langford, M. (2010). A poverty of rights: six ways to fix the MDGs. IDS bulletin, 41(1), 8391.

Murdiansyah, Isnan. (2014). Evaluasi Program Pengentasan Kemiskinan Berbasis Pemberdayaan Masyarakat (Studi Kasus Pada Program Gerdu-Taskin di Kabupaten Malang). Skripsi, STIE Widya Gama, Lumajang.

Ortiz, I. (2002). Defining an Agenda for Poverty Reduction. Asian Development Bank.

Pratama, Y. C. (2014). Analisis faktor-faktor yang mempengaruhi kemiskinan di Indonesia. Esensi: Jurnal Bisnis dan Manajemen, 4(2).

Prawoto, N. (2008). Memahami kemiskinan dan strategi penanggulangannya. Jurnal Ekonomi \& Studi Pembangunan, 9(1), 56-68.

Sendow, M. M., \& Tarore, M. L. (2016). Evaluasi Proses Bantuan Program Keluarga Harapan (PKH) Di Kelurahan Malalayang Satu Kecamatan Malalayang Kota Manado. AGRISOSIOEKONOMI, 12(2A), 315-330..

Sulistyaningrum, W. S. (2013). Masterplan Percepatan dan Perluasan Pengurangan Kemiskinan Indonesia (MP3KI). Kementrian PPN. Bapenas. 
Suratman, Ibrahim, Akmal Ely, Fauzi Ali (2018). Synthesis Model on the Implementation of Public Policy in National Community Empowerment Program in Makassar and Parepare, South Sulawesi. American International Journal of Social Science, 7(3).

Winter, Soren C. (2003). Implementation Perspectives: Status and Reconsideration. Dalam Peters, B Guy \& Pierre, Jon. Handbook of Public Administration. London: Sage Publication Ltd.

Winter, Soren C. (2012). Implementation. Dalam Peters, B Guy \& Pierre, Jon. Handbook of Public Administration. London: Sage Publication Ltd. 